tests might be dispensed with and crude sewage discharged, subject to such conditions as to the provision of screens or detritus tanks as might appear necessary to the central authority.

In arriving at the proposed legal standard and modifications, the limit of the amount of dissolved oxygen absorbed by river water without creating a nuisance has been taken as a basis. The report contains data in regard to this point, and the method of determining the standard so far as regards the permissible amount of dissolved oxygen absorption is given. Tables are also given showing the amount of oxygen absorbed by typical sewage liquors and effluents, together with the theoretical amount of dilution necessary to prevent de-oxygenation beyond a certain limit.

E. A.

BIRTHMARKS AS A TEST OF RACE.

A SUGGESTION was recently made by Herr A Bealz that blue patches in the sacral region furnished a valuable test of race. Such marks are found among the children of Chinese, Koreans, Japanese, and Malays. Mr. Gait, Census Commissioner for India, directed that during the I9I I census inquiries should be made into the question. Much information on the subject will be found in Mr. C. M. Webb's Census Report of Burma for rgI I, recently issued (vol. i., pp. $28 \mathrm{I}$ et seq.). The results are not decisive, and there are at present no means of giving statistics showing the prevalence of these marks. But they are found extensively in Burma, and seem to indicate the existence of a Mongoloid strain in the population.

The question of Melanoglossia was also raised by Surgeon-Captain Maynard, I.M.S., and the prevalence of these black marks on the tongue was also investigated by Mr. Webb (ibid., i. 286), They are very infrequent among Aryan immigrants to Burma, but are found to a large extent among Dravidians, and the pigmentation of the tongue seems to vary with the pigmentation of the skin.

It may be hoped that the question will receive further attention in India, and that inquiries will be made on a wider scale to determine the statistical incidence of these marks.

\section{COLONEL J. S. BILLINGS, M.D.}

TH $\mathrm{HE}$ world of letters, as well as that of science, has sustained a very great loss in the death of Col. J. S. Billings, M.D., who died in New York on March $\mathrm{II}$, at the age of seventy-six. Although born in Indiana, and not in New England, he was nevertheless a typical example of what Oliver Wendell Holmes in "Elsie Venner" calls "the Brahmin caste of New England." In person he was tall and powerfully built. He had a well-poised and shapely head, clear-cut teatures and a very quiet, unassuming and courtly manner.

In spite of his quiet appearance and manner, Dr. Billings was a man of extraordinary energy. $\mathrm{He}$ joined the army of the Northern States in I 86 I as assistant surgeon, but he was medical inspector of the army of the Potomac when the war finished. During the var he aesizned most of the hospitals of the northern army. In 188 he took charge of the Surgeon-General's Library at Washington, a small collection of about two hundred books. During the twenty-two years in which he held the office of director he raised this collection to be one of the finest medical libraries in the world. The catalogue of the library is a stupendous work, giving references not only to medical books, but to pamphlets and extracts, so that it is now indispensable to every worker in medical literature.

From 1891 to 1896 Dr. Billings was professor of hygiene in the University of Pennsylvania, and in 1896 he became director of the New York Public Library, Astor, Lenox and Tilden foundations. This he determined to make one of the seven or eight great libraries of the world, comparable with the British Museum and the Vatican Libraries. He had the satisfaction during his lifetime of seeing a new building provided for the library and the number and value of the books greatly increased. In addition, he arranged for branch libraries to which books could be sent out and consulted apart from the library itself.

Probably no other single man ever did so much for libraries as Dr. Billings. His work was recognised during his lifetime by various universities. He received the honorary degree of LL.D. from five universities--Edinburgh, Harvard, Buda-Pesth, Yale and Johns Hopkins-the D.C.L. from Oxford and the M.D. from Munich and Dublin. But his labours in founding a complete bibliography of medicine by the SurgeonGeneral's Catalogue and the "Index Medicus," in devising a new method of library cataloguing, and in extending and amplifying the work of the New York Public Library so as to make it a great national institution, will only be fully appreciated by posterity. His kindness of heart his affectionate disposition and his charm of manner made him beloved by all who knew him, and it will be long indeed before we see his like again.

LAUDER BRUNTON.

\section{NOTES.}

THE Geological Society of France has awarded the Gaudry medal, the highest honour it can bestow, to Prof. Edward Suess, of the University of Vienna. The Fontannes prize for the best work in stratigraphical geology during the last five years has been awarded to $M$. Jean Boussac.

WE are asked to state that the Committee on $\mathrm{Re}$ search Institute, Chicago, is collecting information about bibliographical material and indexes kept in manuscript by libraries or individuals. Those who have such material in their possession, or know of the whereabouts of any, are desired to communicate with Mr. A. G. S. Josephson, care of the John Crerar Library, Chicago.

IN accordance with the recommendation of the Royal Commission on Vivisection, the Home Secretary has appointed an Advisory Committee to assist him

$$
\text { NO. 2264, VOL. 9I] }
$$

